\title{
The View of the Social Service Positioning of China's Vocational Colleges from Evolvement of History
}

\author{
Xiu-yan HE \\ Department of Sport and Physical Education, Shenzhen Polytechnic, Shenzhen, \\ China
}

Keywords: Vocational colleges, Social service function, Type features, School features.

\begin{abstract}
In China, for the performance of social service function of vocational colleges, a kind of higher educational institutions, the first issue is adhering to the basic principle - "trinity" of social service, education and scientific research, the core issue is forming the type features of vocational colleges' social service, and the key issue is developing the school features of vocational colleges' social service. This is inspired by the evolvement of higher education institution's social service function since its birth in the early 20 th century.
\end{abstract}

\section{Introduction}

In recent years, China's higher vocational education has made great progress, but it still has some shortages in quality. Especially, it faces such problems as incomplete system, weak overall ability, indistinct features, low positioning etc in the aspect of social service. China's higher vocational education is external reason-driven type, the formation and development of its school running philosophy is based on learning from Western higher education, and until today function positioning of China's higher education institutions has something in common with that of Western colleges and universities. Therefore, investigation into the historical evolvement of higher education institution's social service function may bring inspiration for China's vocational colleges to better perform their social service function.

Establishment of Higher Education Institution's Social Service Function

It can be known from historical investigation that higher education institution's social service function sprouted in Europe and blossomed and yielded fruit in the US. Gresham College, founded in 1596, offered physics, geography, navigation and other courses to meet the social needs at that time and allowed its teachers to "provide consultations for scholars, gentlemen, merchants, sailors, shipbuilders, retailers, craftsmen etc"[1]. This is the earliest record about higher education institution's participation in social activities reflected in literature, but such activities were spontaneous and individual and have not been commonly accepted or officially approved, so they can only be regarded as the sprout of higher education institution's social service function. What people have commonly accepted is that higher education institution's social service function originates from the US both in concept and in practice[2]. Benjamin Franklin, politician in the American Colonial Period, and Thomas Jefferson, politician and educationist in the State University Period after the founding of the nation, were the predictors of the concept "higher education institutions directly serve the society". In 1755, Benjamin Franklin, who believed in pragmatistic education view, founded Pennsylvania College on the basis of the junto he set up in his early years, which reflects the principle of "Study for reality and study for application". He discarded religious decayed style of study, ran school catering to society and realized the worldly and utilitarian goal. It is just like what the then 
President Smith said "The college covers nearly all subjects that needed by any profession, and it does its utmost to meet the demands of scholars, merchants, traders, machine makers and low-class practitioners [3]."After that, the concept of social service was further practiced in the State University Period. University of Virginia founded by Thomas Jefferson and triggering the state university movement was one of the examples. Although founders of Pennsylvania College and University of Virginia advocated that higher education institutions should cater to social needs and serve the country, they did not turn this activity function into a function of higher education institutions, in other words, higher education institutions' social service was still realized through their two traditional functions - teaching and scientific research. However, such ideas were the first sign of the concept "higher education institutions directly serve the society" and "the first light of morning".

In the $19^{\text {th }}$ century after the founding of the nation, the American industry has made great progress, but its agricultural development lagged behind, so new agricultural machinery, practical technology and highly qualified technicians were urgently needed to improve American agriculture's efficiency and promote American economic development. However, at that time, American higher education still had strong classical and religious flavor, and higher education institutions were still the "ivory tower" far away from activities and stood high above the society. Obviously, such a kind of higher education made no difference to the development of American economy at that time. It is just like California superintendent's query "What useful occupations can the graduates of our ancient universities engage in[4]?" In 1862, an act that could be called a milestone in American higher education history - Morrill Act was promulgated and implemented, which directly boosted the development of land-grant institutions' movement following the state university movement. Land-grant institutions, taking teaching the subjects related to agriculture and technology as the main target of school running, have promoted American higher education's development towards secularization, popularization and diversification and have cultivated numerous scientific and technological talents needed in the national economic development for the then society. This indicates that American higher education developed from the edge to the center of society, from being passive to active and from being close to open from then on and traditional "ivory tower" started to incline to the social service direction. Nevertheless, the promulgation of Morrill Act did not mean the establishment of American higher education institution's service function, as it only played a catalytic role in the birth of higher education institution's service function, while the school-running thought and practice of University of Wisconsin emerging at the right time was the symbol indicating the formation of thought of and practice in higher education institution's service function [5].

University of Wisconsin, which was founded in 1848 and developed with granted land, adhered to serving the local state's economic development and paid attentio $n$ to agriculture and technological education. It made remarkable achievements in directly serving the society and thus set an example for other higher education institutions. Especially, after Charles Richard Vanhise took office as the president of University of Wisconsin in 1904, university's social service was driven further, allowing University of Wisconsin to enter a new era. According to Charles Richard Vanhise, universities should not have any boundary but should be open. In other words, universities should walk out of the ivory tower to provide services for the society and benefit the development of regional economy in interaction with the society. He also believed that teaching, scientific research and service should be the functions universities 
should have and universities' service should take application of knowledge as the approach, direct service as the direction and other two functions as the basis. The two basic approaches that University of Wisconsin adopted in social service are: first, dissemination of knowledge, including teaching by correspondence, knowledge lecture, public seminar, information service etc; second, expert service, i.e., direct participation in consultation and planning for the state in the aspects of economy, politics, culture etc. University of Wisconsin functionalized social service and identified some basic features of this function, and thus it stirred the wave of universities' social service reform and was followed by other American universities. After that, the form of universities' directly serving the society gradually expanded to setting up training agencies, providing technical consultation, accepting governmental and social research projects, starting a business, carrying out industrial management etc. Linden Ashby, an outstanding British educationist and critics, said "America's contribution to higher education is that it has demolished the bounding walls of university campuses. When Charles Richard Vanhise, President of University of Wisconsin, said that the campus boundaries are national boundaries, he was describing with language a rarely-seen reform in the process of universities' evolvement. The history has demonstrated that this is a correct reform, and other countries have started to imitate this American modep[6]."In 1912, Charles McCarthy, an administrator in charge of legislative data at Wisconsin State Public Library Board, used "Wisconsin Idea" for the first time in his book Wisconsin Idea to summarize Charles Richard Vanhise's school-running ideas and modes of University of Wisconsin. From then on, "Wisconsin Idea" became the pronoun of University of Wisconsin's school-running ideas and modes, and social service formally became the third function of higher education institutions. Moreover, University of Wisconsin became the third glorious milestone following medieval universities and Berlin University in the world's higher education development history.

\section{Evolve ment of Higher Education Institution's Social Service Function}

\section{Social Service Function's Relations with Higher Education Institution's Talent Training Function and Scientific Research Function Become Increasingly Harmonious}

In the Land-grant Institutions Period, there were two kinds of educational concepts coexisting in the US, namely Cornell Plan and Wisconsin Idea. The core of Wisconsin Idea was that higher education institutions should devotedly meet social needs. The formation of this concept was the result of University of Wisconsin's insisting on widely and directly "serving the whole state" and "spreading knowledge to the general public" at that time. Cornell Plan, i.e. the All Purpose Curriculum Plan, reflected the concept "universities serve the society" though, Cornell University realized serving the society in the way of educating people thro ugh offering Business, Administrative Management, Interpersonal Relationship and other courses. Cornell Plan exerted a widespread influence at that time, and its school-running concept finally led part of American universities to the troop of research-oriented universities that regarded developing knowledge as the main function. It can be seen both concepts advocated that higher education institutions should provide service for the society but they had differences in ways. Meanwhile, the establishment of higher education institution's social service function seemed to be a kind of "separation" of University of Wisconsin from the social service included in traditional functions. Additionally, in the real action of University of Wisconsin, whether "dissemination of 
knowledge" or "expert service" had a problem - whether it is to the benefit of improving teaching and scientific research levels. In practice, the phenomenon "social service lowers higher education institution's level of running school" existed [7]. Therefore, it was inevitable that higher education institution's social service function incurred criticism and blame at the beginning of its establishment. Some people directly criticized Vanhise's "dissemination of knowledge" and "expert service that "University of Wisconsin's knowledge spreading work has lowered the academic level of universities", "The University has overreached itself. Is it a 'state university' or 'a university establishing the state'[8]?"

Since the establishment of higher education institution's social service function, social development has gone through the second and the third technical revolution respectively symbolized by wide application of electrical technology and appearance and application of electronic computers, atomic energy and space technology, and it is experiencing the fourth technical revolution that centers on information technology. The establishment of social service function allowed higher education institutions to step from the edge to the center of society and thus allowed them to give fullest play of their third function. Western countries started to not only pay attention to "purely scientific" research, even at Humboldt University, but also valued practical scientific research featuring service. In the 1940s, with the appearance of the third technical revolution, American government not only encouraged higher education institutions to play a role in the military-industry complex to raise higher education institution's social service to the level of national defense but also carried out university-enterprise cooperation integrating talent cultivation, the science park (Silicon Valley) combining scientific research and social service, and university-enterprise cooperative research centers. Since the 1970s, to catering to the needs of information society, another kind of universities - interactive universities was born at the right moment. The main duty of these new-type universities was to establish a kind of interactive relation with the local area. Undoubtedly, only when the three main functions of interactive universities together play a role can this objective be realized. Numerous examples have indicated that rationalist's view of university and utilitarian's view of university have moved from opposition to integration and relationships between the three functions tend to be harmonious. If we say social service function was a kind of differentiation from teaching and scientific research at the beginning of its birth, then current "triune" social service is in harmony with talent cultivation and scientific research.

\section{Higher Education Institution's Social Service Presents More Type Features}

Since the modern times, following continuous development of society, the types of higher education institutions have presented a diversified development trend, especially since the functionalization of higher education institution's social service, the types of higher education institutions have been greatly enriched. According to the Carnegie Classification, the land-grant movement, community college movement and interactive university movement following the state university movement finally resulted in that American higher education institutions formed six main types, which are stable at present[9]: research-oriented universities, master-level universities, bachelor-level universities and colleges, associated bachelor-level colleges, specialized agencies, and ethnic colleges and universities; France formed a higher education system containing the three systems of universities, grandes coles and short-term higher education; the UK formed higher education institution types of traditional universities, polytechnics and open universities; and Japan's higher 
education institution types include universities, short-term universities, special universities and colleges, special training schools, open universities etc [10] .

Modern society has closely connected with higher education institutions, and the social needs for higher education institutions tend to be diversified. It is the diverse social needs that have given birth to diversified higher education. In addition, different types of higher education institutions provide different services for the society, thus forming their own type features. Generally, social service of top-level research-oriented universities tends to be scientific research service-oriented, that of general higher education institutions tends to be teaching service-oriented, and that of vocational colleges is technology and skill service-oriented. For example, American research-oriented universities, relying on their own strength in scientific research, constantly move from traditional passive service to active market-oriented business, attach great importance to direct use of scientific and technological achievements in industrial enterprises, and actively carry out market-oriented business [11]. The first high-tech zone established by Stanford University in 1951 - Stanford Industrial Park is an outstanding representative of higher education institutions' serving the society with their advantages in scientific research; MIT, an entrepreneurial university, has set up more than 8,500 factories and offices in 50 states throughout the US, so it is an outstanding representative of higher education institutions' serving the society through doing pioneering work with their advantages in scientific research. Community colleges, which represent the type of American higher vocational education, have been endowed with the mission of providing full-service for communities since their birth. The features of community colleges are providing comprehensive, considerate and efficient social service for communities and meeting individual needs of society. Services provided by community colleges have made great contributions to American economic development and social progress. Clark Kerr, a famous American higher educationist pointed out that "The invention of two-year community colleges is a great reform of American higher education in the $20^{\text {th }}$ century [12]."

\section{Higher Education Institution's Social Service Presents More Distinct School Features}

In a long period after the founding of the US, localism held a dominant position, and the Morrill Act I breeding the social function of higher education institutions presented rich localism characteristics. As University of Wisconsin is a land-grant institution developing on the basis of a state university, its social service area, scope and object had distinct locality. Especially, it set up the Wisconsin State University Development Department responsible for social service. It faced the society in the way of direct service, and its service approaches such as dissertation of knowledge, expert service etc had distinct uniqueness. It is these distinct social service features of University of Wisconsin that made the social service function "get out from the shell". Therefore, it can be seen from the origin that higher education institution's social service function is a brief summary of the distinct features of University of Wisconsin's social service, indicating that higher education institution must have their own features of social service.

Having gone through more than one century's evolvement, higher education institutions start to pay attention to giving play to their own social service function and their social service features have become increasingly distinct. Concerning service area, globalization has given it more space to choose. Higher education 
institutions can be characterized by either localization or internationalization, but in general, higher education institutions have gone global and become the "service station" of the whole world, reflecting the trend of social service internationalization. For example, Harvard University established the Harvard's Center for International Affairs in 1958, hoping to exert an influence on the making of policies that affected international affairs through this center so as to make contributions to international understanding, improving international order and indirectly maintaining world peace[13]. In service scope, scientific and technical revolutions have happened one after another, higher education institution's disciplines and majors have continuously expanded, and the service scope has turned to microelectronics, computer technology, material science, energy $R \& D$, bioengineering technology and other fields. A majority of famous universities in the world are well-known for their featured colleges, disciplines and specialized social service, such as Harvard University's School of Government, Yale University's School of Drama, and University of California (Berkeley)'s School of Chemistry. Concerning service object, with the establishment of higher education institution's global vision, the whole world becomes the service object. It is just like what Derek Bok, former President of Harvard University, has said "Universities even need to participate in solving such international issues as environmental protection, disarmament etc." Therefore, higher education institutions have a wide range of special objects to choose, which can avoid repetition and make it easy to form their own features. For example, Germany's industrial vocational colleges are dedicated to providing service for the employees of their own enterprises. Regarding service forms and contents, different higher education institutions have developed their own distinct social service forms based on their own situations and the service contents have become increasingly diverse. In the US, for example, the main forms and contents of higher education institution's social service include[14]: carrying out adult education and further education; carrying out technology promotion service; establishing scientific (ind ustrial) parks; setting up university-enterprise joint research centers; undertaking scientific research projects of governments, enterprises and public institutions through authenticating scientific research contracts; establishing partnership with enterprise for mutual help; providing various kinds of consultations; setting up joint-venture enterprises; and opening libraries, labs, classrooms facilities etc to the society.

\section{Positioning of China Vocational College's Social Service Function in the Evolve ment of Higher Education Institution's Social Service Function}

\section{Principle: Adhering to "trinity" of Social Service, Education and Scientific Research}

In a broad sense, all activities of higher education institutions, regardless of education or scientific research, are for the purpose of serving the society. In the unitary-function Medieval Universities Period, higher education institutions cultivated doctors, lawyers and other professionals needed by the then society, reflecting that teaching served the society. It is just like what John S. Brubacher has said "Medieval university education is mainly vocational education [15]." In the binary-function Humboldt University Period, although Humboldt University's school-running thought stressed "purely scientific" research, some scientists boldly and actively promoted their own research results to enterprises, reflecting that higher education institutions extended their knowledge function to social service function. Therefore, the three main functions of higher education institutions are "trinity", where teaching and 
scientific research are the basis of service, i.e. the source, and social service is the extension of teaching and scientific research, i.e. the flow. If higher education institutions only emphasize serving the society and attach no importance to academic development, then service would become water without a source and a tree without roosts. In fact, this is just the nature of "Wisconsin Idea". On the one hand, it was a new thing at that time, and on the other hand, it incurred blame from conservative force because it might not always reach predicted effects in the practice process.

Following this principle, importance should be attached to the two aspects concerning China vocational college's social service function: first, regarding teaching and education as the first function of vocational colleges. The most fundamental difference between universities and other social institutions is that universities carry out teaching activities to cultivate high-quality talents. If only carrying out direct social service without teaching activities, vocational colleges will be same as enterprises, social agencies or charitable organizations and thus lose their value and legitimacy of existence. American community colleges are typical social service-oriented higher education institutions. Their social service is realized through providing comprehensive general education, vocational education, compensation education and adult education for communities, and their other direct service is established upon the basis of teaching and education. Second, valuing scientific research and regarding scientific research as the great support to higher education institution's social service. There is no controversy that higher vocational education has become a type of China's higher education, and next, hierarchy of vocational colleges will be well-reasoned (National Model Higher Vocational College Program is a kind of preliminary hierarchy of vocational colleges to some extent). Undoubtedly, like the hierarchy of common colleges and universities, scientific research strength will become main evidence of hierarchy of China's vocational colleges as well. Same as high-level research-oriented universities, high-level vocational colleges will carry out high-level social service underpinned by strong scientific research strength. Therefore, vocational colleges should attach great importance to scientific research and conduct scientific research with vocational college's characteristics to continuously improve their own social service level. In short, positioning of vocational college's social service function should adhere to the principle of "trinity" of the three main functions, i.e. taking knowledge resources as the support, application of knowledge as the approach, direct service as the direction and teaching and scientific research as the basis.

\section{Core: Forming the Type Features of Vocational College's Social Service}

Higher education institutions have sociality but are not aliens. Today, in the $21^{\text {st }}$ century, relation between higher education institutions and the society becomes increasingly close, and many colleges and universities born late were established to meet the specific need of serving the society. For example, the birth of dual-system vocational colleges as the third part of German higher education was to meet the needs of the then industrial circle for high-level practical technical talents. Meanwhile, the institutional types of higher education become increasingly diverse, with different types corresponding to different social needs. Therefore, different types of higher education institutions should develop their own type features of social service to meet specific social needs.

China's vocational colleges should develop their own type features. First, they should clearly know what type of higher education institutions they are. In 2006, the 
Ministry of Education specified in the Opinions on Comprehensively Improving the Teaching Quality of Higher Vocational Education that higher vocational education is a "type" of higher education. So, what type of higher education institutions do vocational colleges belong to? Some people, starting from the perspective corresponding to the three main functions of higher education, suggest dividing China's existing higher education institutions into academic research-oriented ones, industry-oriented ones and vocation-oriented ones, which respectively correspond to scientific exploration function, education function and service function [16]. I quite agree to this suggestion. It can be seen from the real situation that vocational colleges are a kind of vocation-oriented higher education institutions with serving the society as their main function. It is because the accurate positioning of German dual-system vocational colleges that allows the development of "dual system" to be world-renowned as a form of higher vocational education. Second, the objective of talent cultivation should reflect the type features of vocational colleges. The objective of talent cultivation is an important feature to distinguish the type of higher education institutions, and formation of the type features of vocational colleges first depends on characteristic talent cultivation objective. The determination of China higher education's talent cultivation objective has gone through a rheological process. The objective proposed in 1998 was cultivating "practical talents", then the objective was adjusted to cultivating "practical talents specialized in high-technology" in 2000, and it was further specified as cultivating "highly-skilled talents in 2004. This changing process reflects the society's needs for higher vocational education have been constantly changing and vocational colleges should provide highly-skilled talent cultivation service for the society, which is the fundamental feature that makes vocational colleges different from other types of higher education institutions. If vocational colleges participate in cultivation of disciplinary talents and specialized talents, it is actually an unwise move like "farm on other people's land but neglect one self's land", so they have no competitiveness in the aspect of social service ability. Third, scientific research should reflect the type features of vocational colleges. Expert service in the Wisconsin Idea mainly refers to generalization of scientific research achievements, which belongs to the category of application-oriented research and development-oriented research. Compared with regular institutions of higher education, China vocational colleges' overall strength in scientific research is still weak and needs continuous improvement. China vocational colleges' scientific research has four main characteristics, namely vocational characteristic, applied technology characteristic, regional characteristic and open characteristic. They should highlight application-oriented and development-oriented research and cater to enterprises to undertake horizontal scientific research projects aimed at providing service for scientific and technological development to improve product quality and productivity. One of the reasons for the birth of Wisconsin Idea is the uniqueness of the social service mode of University of Wisconsin. The unique social service features of China vocational colleges are mainly reflected in: first, the regional nature of service is more obvious, service items are more specific, and the efficiency is higher; second, they can provide more practical adult education, skill training, verification and certification of occupational qualific ations and other services.

\section{Key: Developing the School Features of Vocational Colleges}

In recent years, deviation and mal-position have occurred to China's higher education reform. The main reason for this is that we do not understand well the mission and 
functions of modern universities, or we equate them with "enterprises" which engage in material production, or we imagine them as the ideological "battle field", or we generalize their functions and endow them with too much social responsibility [17]. Indeed, today is highly market-oriented, so university's autonomy is increasingly influenced by common control and governments tend to purchase university's social service to realize effective control over universities. Therefore, to some extent, higher education institutions have to follow government's commands and thus social service has become the lifeblood of higher education institutions and social service function has become an important index to measure the comprehensive strength of a higher education institution. To enhance the competitiveness of social service, higher education institutions have included the service characteristics into the characteristic strategy system developed by themselves.

If we say higher education institutions' developing their own type features to avoid "standing in wrong line" reflects a kind of division of social service, then higher education institutions' developing their own school features and trying their best to join the troop of higher vocational education reflects a kind of comparative advantage. First of all, they should have characteristic specialties. Only when a higher education institution has characteristic specialties can it provide characteristic social service. The popularity of China vocational college's social service relies on characteristic specialties. For example, it is a common sense that Chengdu is well-known for vehicle inspection, test and maintenance specialty, Zhejiang for applied numerical control technology specialty, and Qingdao for logistics management specialty. It is these characteristic specialties that have built the local brand of vocational college's social service. Secondly, they should have characteristic scientific research. Vocational college's scientific research has strong regional features, which is usually application-oriented and development-oriented and directly serves enterprises. In the context where scientific research strength is generally weak, those vocational colleges that have certain strength tend to form the scientific research strength - "When others do not have, I have, and when others have, I am more superior". Thirdly, they should have characteristic social service mode. The formation of characteristic social service mode needs to be supported by strong school-running strength and reflects a school's radiating capacity, so it is easy for a vocational college to form comparative advantages among the institutions of the same kind. For example, Jinhua polytechnic's "five-in-one" social service mode and Shenzhen Polytechnic's pairing-assistance mode, science and technology service mode and faculty training mode combining local and long-distance training have brought about great social influences.

\section{Conclusion}

According to Nayman, "Higher education institutions are not only the axis of social and economic development but also the axis of cultural development, and it should be the source of the surrounding society [18]." As long as vocational colleges adhere to the principle - "trinity" of social service, education and scientific research to form their own type features and school features, they will become a genuine "service station" for continuous progress and development of the society no matter how time and space change. 


\section{References}

[1] Richard Aldrich, translated by Zhu Huifang et al. An Introduction to the History of Education [M]. Beijing: Peoplehe History of Education ng et

[2] Zhu Guoren. From "Ivory Tower" to "Social Service Station" - Evolvement History of Higher Education Institution's Social Service Function [J]. Tsinghua Journal of Education, 1999(1):34.

[3] Teng Dachun. History of American Education. Beijing: People's Education Press, 1994.136.

[4] Wang Yingie. Development and Reform of American Higher Education. Beijing: People4.136.ation for continuous

[5] Xu Shucheng. Study on the History of American Higher Education Institution: People4.136.atioFunction [D]. Master dissertation of Shaanxi Normal University, 2003-04:17.

[6] Derek Bok, translated by $\mathrm{Xu}$ Xiaozhou et al. Beyond the Ivory Tower [M]. Hangzhou: Zhejiang Education Publishing House, 2001.73.

[7] Wang Liangsheng. Review of Wisconsin Idea [J]. Journal of Xiangtan University (Philosophy and Social Science) [J], 1995(1):121.

[8] John S. Brubacher and Willis Rudy, Higher Education in Transition, Transition Publishers, 1997, p167.

[9] The Carnegie Classification of Institutions of Higher Education [EB/OL].http://learning.sohu.com/20000523/100015.html.2005-08-06.

[10] Chen Min. Study on Chinans of Higher Education [EB/OL]. http://learning.sohu.com/20000523/100015.html.2005-08-06.,1995(1):121.lopment of the society no matter

[11] Yu Xuelian. Experience of American Research-oriented Universities in Function Development and Evolution [J]. Comparative Education Review, 2007(5):20.

[12]Steven Bvint, Jerome Karabel, The Diverted Dream: Community College and the Promise or Education Opportunity in America: 1900-1985, 1989, p1.

[13] Zhong Binglin. Conceptual and Institutional innovation [J]. Journal of Beijing Normal University (Social Sciences), 2003(5):6.

[14] Wang Yingjie. Discussion on the Social Service Function of American Higher Education Institutions [J]. Foreign Education Trends, 1998(5):11.

[15] Sun Peiqing, Ren Zhongyin. Short History of Comparative Studies of Chinese and Foreign Education (Ancient Volume) [M]. Jinan: Shandong Education Publishing House, 1997.501.

[16] Liu Shu, Guo Jianghui. Current Higher Education Institution Classification Model: Limitations and Transcendence [J]. Journal of Hebei University (Philosophy and Social Science), 2006(4):81-82.

[17] Gong Fang. "Should Be" and "Can Be" of Modern University S ystem Innovation - Meaning of Building First-class Universities [J]. Journal of Higher Education, 2006(7):44. 
[18] Dellagore Jubb Nayman, translated by Ling Hua et al. Discussion on World Higher Education [M]. Beijing: National Science Publishing House, 1982.167. 